\title{
MEN1 in children and adolescents: Data from patients of a regional referral center for hereditary endocrine tumors
}

\author{
Letizia Vannucci ${ }^{1}$ - Francesca Marini ${ }^{1} \cdot$ Francesca Giusti $^{2} \cdot$ Simone Ciuffi $^{1}$. \\ Francesco Tonelli ${ }^{2} \cdot$ Maria Luisa Brandi $\mathbb{D}^{2}$
}

Received: 6 March 2017 / Accepted: 5 May 2017

(C) Springer Science+Business Media New York 2017

\begin{abstract}
Purpose To retrospectively evaluate the age of onset of MEN1-associated lesions in a group of affected children and adolescents and to compare the clinical features of our series with the evidence derived from the literature.

Methods The study population consisted of 22 Italian children and adolescents (age 6-31 years at the time of the inclusion in this study) all with a clinical and/or a genetic diagnosis of MEN1 performed before the age of 16 who have been followed-up regularly from 1998 to 2016 at the Regional Referral Center for Hereditary Endocrine Tumors. Clinical, biochemical, imaging and genetic data have been collected for each patient.

Results Ten subjects (45.5\%) have not yet presented any clinical/biochemical/radiological manifestation of MEN1 disease, whereas 12 patients $(54.5 \%)$ developed at least one MEN1-associated endocrine manifestation. The second group of patients was significantly older than the first one. The most frequent manifestation was primary hyperparathyroidism (50\%), followed by pituitary tumors (prolactinomas) (31.8\%) and nonfunctioning pancreatic neuroendocrine tumors $(9 \%)$. The earliest cases of primary hyperparathyroidism and prolactinoma were a 12-year-old girl and a 13-year-old boy, respectively.

Conclusions MEN1 disease seems to present with different features in children and adolescents from those in adults.
\end{abstract}

Maria Luisa Brandi

marialuisa.brandi@unifi.it

1 Department of Surgery and Translational Medicine, University of Florence, Viale Pieraccini 6, 50139 Florence, Italy

2 Department of Surgery and Translational Medicine, University of Florence, Largo Palagi 1, 50139 Florence, Italy
Our study confirms the fundamental importance of screening for tumors in young MEN1 patients beginning in early childhood, in order to avoid diagnostic and therapeutic delays.

Keywords Multiple endocrine neoplasia type $1 \cdot$ Clinical diagnosis $\cdot$ Genetic diagnosis $\cdot$ Children and adolescents $\cdot$ Early onset $\cdot$ Disease screening

\section{Introduction}

Multiple endocrine neoplasia type 1 (MEN1) is a rare autosomal dominant inherited multiple endocrine tumor syndrome, mainly affecting parathyroid glands, gastroentero-pancreatic neuroendocrine tissues, and anterior pituitary [1].

In children and adolescents, the MEN1 diagnosis is principally made by the genetic screening of the MENI gene, within a pedigree with a previously identified MEN1 mutation.

Penetrance of MEN1 mutations is age-dependent; however, although it appears to be almost negligible before 5 years of age, clinical manifestations of MEN1 have occurred in some patients by the age of 5 years. Therefore, Clinical Guidelines suggest the performance of genetic testing in asymptomatic relatives of MEN1 mutated patients as soon as possible, certainly within the first decade of life, hopefully before 5 years of age [2].

Genetic testing presents numerous advantages: it requires only a single blood sample, it can be performed at any age and, in theory, it does not need to be repeated during life. A negative genetic result allows us to avoid further MEN1 clinical surveillance in those subjects. It is fundamental to regularly monitor all patients at high risk of developing 
MEN1-associated tumors (index cases and germline mutated MEN1 carriers) using a specific screening program, in order to promptly diagnose tumors throughout life without any delay.

Screening should start during early childhood [3] and continue throughout life, as the first clinical manifestations can arise even during the eighth decade of life in some patients [2]. Table 1 shows the age of initiation and modalities of screening for each of the main MEN1-associated tumors according to the latest MEN1 Guidelines; respective levels of clinical evidence are also indicated [2].

The aim of our retrospective study is to evaluate the age of onset of MEN1-associated lesions in a group of affected Italian children and adolescents and to compare the clinical features of our series with evidence on MEN1 in young patients derived from literature.

\section{Subjects and methods}

The study population consists of 22 Italian children and adolescents, aged from 6 to 31 years at the time of the enrollment in the present study, all with a clinical and/or genetic diagnosis of MEN1. All patients were regularly followed-up at the Regional Referral Center for Hereditary Endocrine Tumors of the Endocrine Unit in the Department of Surgery and Translational Medicine, University Hospital
Careggi in Florence from 1998 to 2016. A total of 160 MEN1 patients (55 males and 105 females) were referred to our Center and regularly evaluated during the same period of time. The study was approved by the local ethics committee of Careggi Hospital, and informed consent has been obtained from all legal guardians of our minor patients.

Patients were annually tested for parathyroid hormone (PTH) and calcemia, prolactin (PRL), insulin-like growth factor 1 (IGF-1), growth-hormone (GH), thyroidstimulating hormone (TSH), adrenocorticotropic hormone (ACTH), gonadotropins, glycaemia, plasma insulin, Cpeptide, serum gastrin, plasma vasoactive intestinal peptide (VIP), pancreatic polypeptide (PP), glucagon, and chromogranin-A (CgA). Secretin provocative test was performed every 12-18 months beginning at the age of 15 . Adrenal function was evaluated in case of clinical manifestations. Imaging tests were performed in the presence of biochemical alterations and/or clinical signs and symptoms. Particularly, abdominal computed tomography (CT)/magnetic resonance imaging (MRI) were performed every 2-3 years; if scintigraphy with somatostatin analogous was positive in presence of gastro-entero-pancreatic neuroendocrine tumors (GEP-NETs), it was repeated every 2 years.

Clinical, biochemical, imaging and genetic data were collected and recorded in a specific database in association

Table 1 Diagnostic screening of MEN1-associated tumors according to the latest MEN1 guidelines

\begin{tabular}{|c|c|c|c|c|c|}
\hline Men1-associated disease & $\begin{array}{l}\text { Age of } \\
\text { initiation } \\
\text { (years) }\end{array}$ & Laboratory parameters & $\begin{array}{l}\text { Level of clinical } \\
\text { evidence }\end{array}$ & Imaging test & $\begin{array}{l}\text { Level of clinical } \\
\text { evidence }\end{array}$ \\
\hline Primary hyperparathyroidism & 8 & $\begin{array}{l}\text { Plasma calcium and PTH } \\
\text { (annually) }\end{array}$ & $\begin{array}{l}\text { Strong } \\
\text { recommendation; high } \\
\text { quality }\end{array}$ & - & - \\
\hline Anterior pituitary tumors & 5 & $\begin{array}{l}\text { Plasma PRL and IGF-1 } \\
\text { (annually) }\end{array}$ & $\begin{array}{l}\text { Weak recommendation; } \\
\text { moderate quality }\end{array}$ & MRI every 3 years & $\begin{array}{l}\text { Weak } \\
\text { recommendation; } \\
\text { low quality }\end{array}$ \\
\hline Gastrinoma & 20 & $\begin{array}{l}\text { Fasting serum gastrin } \\
\text { (annually) }( \pm \text { gastric } \mathrm{pH} \text {; } \\
\text { diagnostic values }<2)\end{array}$ & $\begin{array}{l}\text { Weak recommendation; } \\
\text { low quality }\end{array}$ & - & - \\
\hline Insulinoma & 5 & $\begin{array}{l}\text { Fasting plasma insulin and } \\
\text { glucose (annually) }\end{array}$ & $\begin{array}{l}\text { Weak recommendation; } \\
\text { low quality }\end{array}$ & - & - \\
\hline $\begin{array}{l}\text { Other pancreatic NET } \\
\text { (glucagonoma, VIPoma, } \\
\text { nonfunctioning pancreatic NET) }\end{array}$ & $<10$ & $\begin{array}{l}\text { Plasma glucagon, VIP, PP, } \\
\text { CgA (annually) }\end{array}$ & $\begin{array}{l}\text { Weak recommendation; } \\
\text { low quality }\end{array}$ & $\begin{array}{l}\text { CT, MRI or EUS } \\
\text { annually }\end{array}$ & $\begin{array}{l}\text { Weak } \\
\text { recommendation; } \\
\text { low quality }\end{array}$ \\
\hline *Bronchial and thymic carcinoid & 15 & $\begin{array}{l}\text { None (no increase in plasma } \\
\mathrm{CgA} \text { levels has been observed) }\end{array}$ & $\begin{array}{l}\text { Strong } \\
\text { recommendation; high } \\
\text { quality }\end{array}$ & $\begin{array}{l}\text { Chest CT or MRI } \\
\text { every } 1-2 \text { years }\end{array}$ & $\begin{array}{l}\text { Weak } \\
\text { recommendation; } \\
\text { very low quality }\end{array}$ \\
\hline Adrenal tumors & $<10$ & $\begin{array}{l}\text { Only in case of suspected } \\
\text { clinical manifestations and/or if } \\
\text { the tumor size is }>1 \mathrm{~cm}\end{array}$ & $\begin{array}{l}\text { Strong } \\
\text { recommendation; } \\
\text { moderate quality }\end{array}$ & $\begin{array}{l}\text { Abdominal CT or } \\
\text { MRI annually with } \\
\text { pancreatic imaging }\end{array}$ & $\begin{array}{l}\text { Weak } \\
\text { recommendation; } \\
\text { low quality }\end{array}$ \\
\hline
\end{tabular}

Notes: *screening should be performed even after prophylactic thymectomy

$N E T$ neuroendocrine tumor, $P T H$ parathyroid hormone, $P R L$ prolactin, $I G F-1$ insulin-like growth factor-1, VIP vasoactive intestinal peptide, $P P$ pancreatic polypeptide, $C g A$ chromogranin-A, $C T$ computed tomography, MRI magnetic resonance imaging, EUS endoscopic ultrasound, $c m$ centimeter 
with a specific, unique anonymous alphanumeric code to assure the privacy of the patient, and each patient was referred to in the study only by this identifying code. Data collected in the database included: birth date, gender, age at genetic diagnosis (date of genetic test), MEN1 gene mutation, first MEN1 manifestation, age at clinical diagnosis (date of the first clinical manifestation, defined as the MEN1-associated lesion that was firstly discovered), MEN1-associated endocrine manifestations, other comorbidities, MEN1-related surgical history and pharmacological treatments.

Data included in the database are presented as percentages, means and standard deviations and medians (range).

The comparison between the median age of MEN1 patients with and without at least one endocrine manifestation of the disease was performed by Mann-Whitney $U$ test. A $p$-value $<0.05$ was considered as the level of statistical significance.

Twenty-one patients underwent the MEN1 genetic test after a first degree relative was diagnosed with a MEN1 mutation; each was tested for the specific pedigreeassociated mutation by a PCR-based Sanger sequencing of the specific mutation-containing exon or intron-exon junction of the MEN1 gene. One patient was a proband; he underwent MEN1 mutational analysis before all his family members.

\section{Results}

Clinical, genetic, and therapeutic features of our series of young MEN1 patients are summarized in Table 2.

A genetic and/or clinical diagnosis of MEN1 syndrome was performed in all 22 subjects before the age of 16: 10 females $(45.5 \%)$ and 12 males $(54.5 \%)$. The cases were familial, belonging to 14 different MEN1 pedigrees, and a MEN1 mutation was identified in all cases. Only one patient (case 4, Table 2) was a proband presenting the same age of both genetic and clinical diagnosis, whose family has been subsequently screened for MEN1 mutation. All other cases were family members identified as MEN1 first via genetic screening. The mean age at genetic diagnosis of MEN1 was $9.4 \pm 3.75$ years (range $0-14$ ). The age at the genetic diagnosis of the proband (case 4, Table 2) was 13 years, whereas the age at MEN1 diagnosis of his brother and sister was 7 and 10, respectively.

Genetic analysis confirmed the absence of mutational hot spots in the MEN1 gene and mutations have been identified all along MEN1 exons (except for exons 5, 6, and 7) and intron-exon junctions (Table 2). In our series of patients, we identified missense, nonsense, frameshift, and splicing site mutations. Two brothers harbored a double mutation on the same MEN1 allele, not associated with a higher aggressiveness of the syndrome (cases 11 and 12, Table 2).

To date, 10 subjects $(45.5 \%)$ [median age 12 years (range 6-16)] have not yet presented any clinical manifestation associated with MEN1 and no abnormalities in biochemical tests or evidence of the disease by imaging examinations were detected (referred to as "still asymptomatic" patients). Conversely, 12 patients $(54.5 \%)$ [median age 22.5 years (range 12-31)] developed at least one MEN1-associated endocrine manifestation; in detail, 10 of these patients were clinically asymptomatic and were diagnosed by routine biochemical tests and/or imaging investigations, whereas only two were symptomatic, showing pituitary tumor-induced headache with visual disturbances and primary hyperparathyroidism (PHPT)-related kidney stones, respectively. A significant difference was found in the median value of age between these two patient groups $(U$-test $=5.0 ; p<0.001)$. Particularly, patients with MEN1-associated lesions were significantly older than MEN1 patients without any clinical/biochemical/radiological manifestation of the syndrome.

The most frequent clinical phenotype was PHPT which was present in 11 patients $(50 \%)$ [six females $(54.5 \%)$ and five males $(45.5 \%)$ ] followed by pituitary tumors (seven cases; $31.8 \%$ ) [four females (57.1\%) and three males (42.9\%)] and pancreatic NETs (pNETs) (two females; 9\%). PHPT was the only manifestation of MEN1 in four cases, while it was associated with other lesions in seven cases.

PHPT was the first MEN1 manifestation in 7 out of 12 patients $(58.3 \%)$ who had developed MEN1-associated clinical and/or biochemical and/or radiological abnormalities; it was symptomatic (presence of a history of kidney stones) in only one out of 11 patients with PHPT (9\%). Asymptomatic PHPT patients $(10 / 11,91 \%)$ were diagnosed by biochemical tests. The earliest case of PHPT was an asymptomatic normocalcemic 12-year-old girl. Patients with low levels of vitamin D were treated with oral supplements to exclude cases of secondary hyperparathyroidism [4].

The patient with symptomatic PHPT underwent surgery and then received pharmacological therapy; five asymptomatic PHPT patients had normocalcemia that did not require therapy and have been monitored with annual calcemia and PTH measurements; the remaining five asymptomatic patients were surgically and/or pharmacologically treated because of hypercalcemia. Particularly, 2/5 patients (40\%) underwent total parathyroidectomy with autograft in the non-dominant forearm, $1 / 5 \quad(20 \%)$ subtotal parathyroidectomy, and $2 / 5(40 \%)$ partial parathyroidectomy (removal of only the single enlarged gland). Three out of five patients who were surgically treated also underwent total thymectomy. Pharmacological treatment of PHPT with calcimimetics (cinacalcet) was performed as first line 


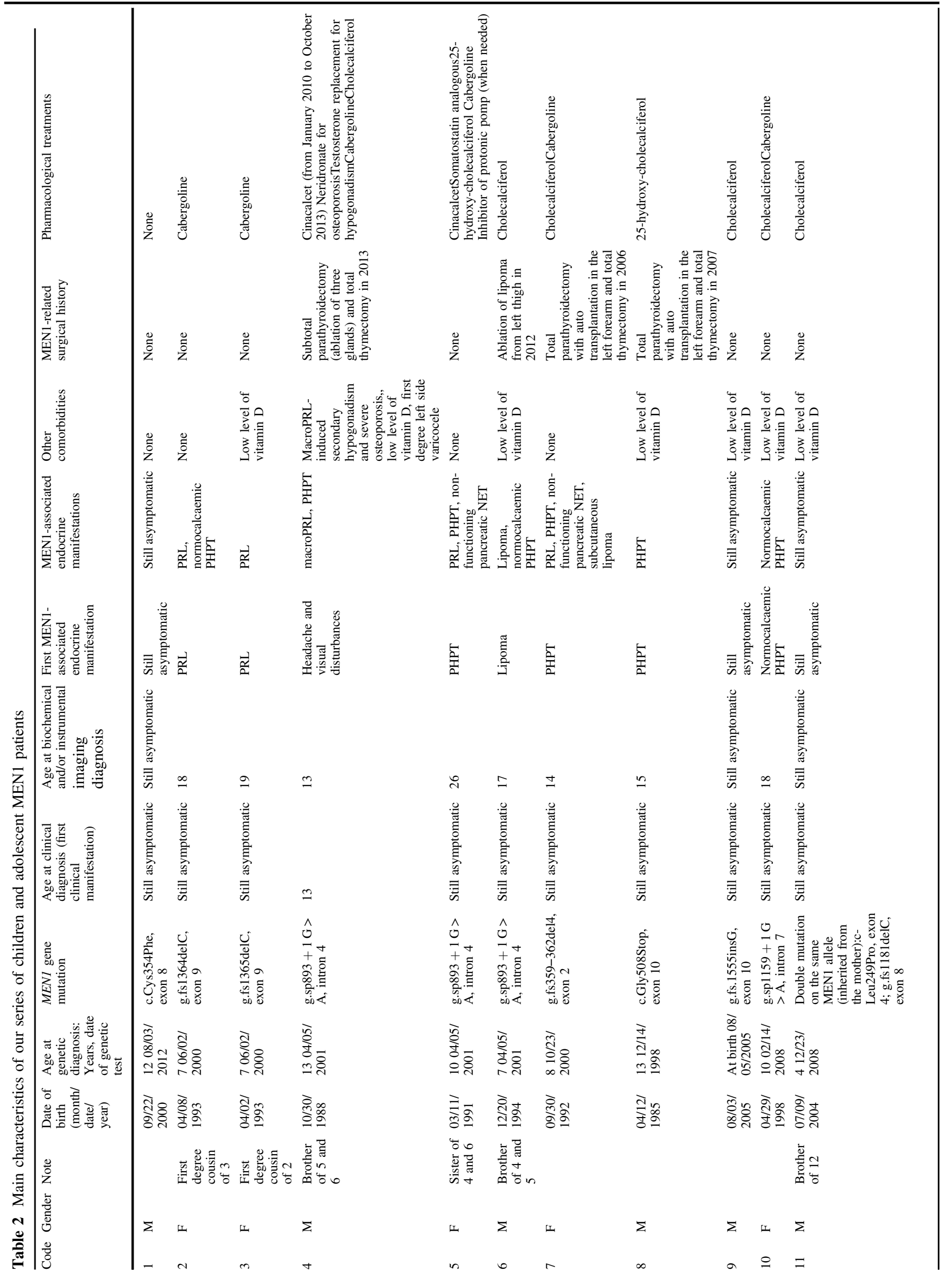




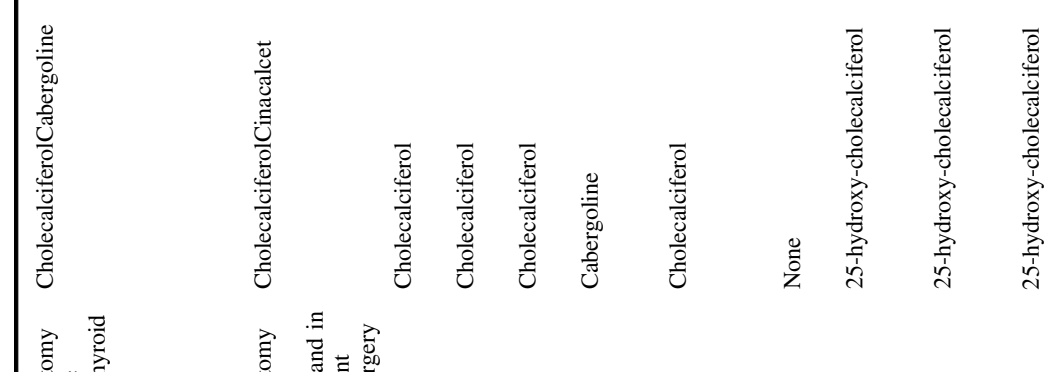

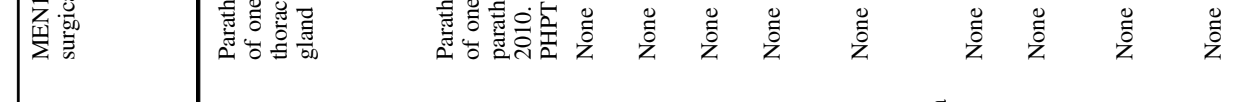

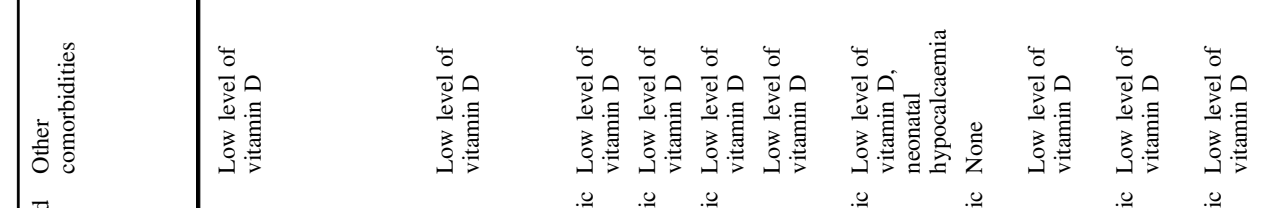


therapy in $2 / 11$ patients $(18 \%)$. To date, cinacalcet is the current therapy in one patient (because she postponed surgery for personal reasons); another patient underwent parathyroidectomy after 3 years of pharmacological therapy; another, who was the only symptomatic patient, was treated with cinacalcet for persistent PHPT after parathyroidectomy. To date, all surgically and/or pharmacologically treated patients for PHPT show normocalcemia.

Pituitary tumors developed in seven patients [four females (57\%) and three males (43\%)]. In one case (14.3\%) the pituitary tumor was the only manifestation of MEN1 disease, whereas it was associated with other lesions in six patients $(85.7 \%)$.

Pituitary tumors were the first manifestation in 4 out of 12 MEN1 patients who showed at least one MEN1-induced clinical and/or laboratory and/or radiological alteration $(33.3 \%)$. All pituitary tumors were prolactinomas, and five of them were clinically asymptomatic microadenomas. The remaining two prolactinomas were macroadenomas; they occurred in two young males (cases 4 and 17, Table 2). One of these two patients, who was a proband and represented the earliest case of prolactinoma in our series (13 years old), complained of headache and visual disturbances and had a macroprolactinoma-induced secondary hypogonadism, which led to a severe osteoporosis requiring pharmacological treatment with testosterone and neridronate (case 4, Table 2). The other patient (case 17, Table 2) was clinically asymptomatic. Prolactinomas were associated with a normal remaining pituitary function in all patients except the proband. Pharmacological approach with dopamine-agonists as first-line therapy was performed in all patients. This is their current therapy, which allows good control of the pituitary disease in all patients to date, except for those with macroprolactinoma who show hyperprolactinemia (case 4 and 17, Table 2).

Two females developed nonfunctioning pNETs, both revealed by CT. Both pNETs were associated with other MEN1-related lesions. One patient had two non-secreting lesions of 0.6 and 0.7 centimeters $(\mathrm{cm})$ in size at the pancreatic head/body and body/tail crosses, respectively (case 7, Table 2); the other patient had a $1.3 \mathrm{~cm}$ lesion in the pancreatic tail, which secreted glucagon and scintigraphy with somatostatin analogous was positive, so pharmacological therapy with somatostatin analogous was performed as first-line therapy (case 5, Table 2). To date, neither pNET has been removed because they are stable in size at annual imaging follow-up. No cases of insulinoma, gastrinoma or other GEP-NETs occurred in our small series of MEN1 patients. Patients who underwent secretin provocative test showed a normal response.

Lipomas were present in two patients and, notably, this was the first clinical sign of MEN1 disease in one patient (case 6, Table 2).
To date, no other MEN1-associated lesions have manifested in our patients, particularly no cases of adrenal lesions or thymic NET have emerged.

Notably, neonatal hypocalcaemia occurred in one patient (case 18, Table 2), because his mother had hyperparathyroidism during pregnancy (MEN1 not yet diagnosed in the mother).

\section{Discussion}

MEN1 is a rare disease and the penetrance of MEN1 mutations is known to be progressive during life [3]. This is confirmed in our study, which shows that patients with at least one manifestation of MEN1 syndrome are significantly older than those without any clinical/biochemical/radiological expression of the disease. Hence, large clinical studies in children with MEN1 are lacking and most of the current knowledge is related to MEN1 in adults.

Evidence of MEN1 in childhood mainly derives from case reports, but a retrospective study performed in a large group of 160 MEN1 patients (96 females and 64 males) under 21 years of age has recently been published by Goudet et al. [3]. At the time of the study, the age of 21 had been reached by $67 \%$ of patients, the age of 15 by $90 \%$, the age of 10 by $97 \%$, and the age of 5 by all patients. The study showed that the frequency of MEN1-associated tumors in children was quite different than adults: PHPT was the most frequent clinical manifestation also in children (75\%), whereas, contrary to adults, pituitary adenomas were the second in frequency (34\%), followed by GEP-NET $(23 \%)$. These results are confirmed in our series, and they may be partly explained by different diagnostic approaches between young and adult MEN1 patients. Particularly, regular screening of MEN1 patients beginning in childhood allows prompt diagnosis of still asymptomatic tumors, whereas MEN1 diagnosis in adults might more often derive from tumor-associated clinical symptomatology.

Our study also showed that PHPT was the most frequent manifestation of onset in young MEN1 patients (58.3\%), whereas prolactinoma was the second most frequent manifestation of MEN1 onset (33.3\%). Similarly, Goudet et al. [3] showed that PHPT was the first laboratory and/or clinical manifestation of the syndrome in $56 \%$ of patients, while MEN1 onset was revealed by a pituitary adenoma in $21 \%$ of cases.

In agreement with Goudet et al. [3], PHPT was mainly asymptomatic in our series of MEN1 patients (10/11 patients; 91\%), and only one young girl presented with symptomatic urolithiasis. All cases of PHPT occurred after 10 years of age in our study group, and this was partly in agreement with the study of Goudet et al. [3], in which $90 \%$ of PHPT cases occurred after 10 years, but the earliest 
asymptomatic and symptomatic cases were a 4-year-old boy and an 8-year-old girl, respectively [3].

One single case of a severe complication of MEN1associated PHPT is reported in literature: a MEN1 boy experiencing a PHPT-related ischemic stroke, in absence of hypertension, at the age of 14 [5].

Thirteen clinical cases (cases 1 to 13) of children and adolescents with MEN1-related pituitary disease derived from literature are summarized in Table 3 .

MEN1-associated pituitary adenomas are known to be more frequent in females [2], with a 3.2/1 female/male ratio during the pediatric age, although macroadenomas appear to be more frequent in young males than in young females [3], and a greater aggressiveness of pituitary tumors in young males rather than in young females seems to arise from current evidence [3, 6-9] (cases 1-4, Table 3). Results from our series appear to confirm this aspect, as patients with PRL-secreting macroadenoma were all young males (case 4 and 17, Table 2).

Nevertheless, literature also reported the case of a 6.5year-old girl with an invasive suprasellar pituitary macroadenoma [10] (case 5, Table 3).

In agreement with Goudet et al. [3], no pituitary tumor occurred before the age of 10 in our series of patients, although it could not be excluded that the real age of onset of the macroprolactinoma in our proband, which was diagnosed at age 13, was earlier. MEN1 Guidelines suggest an earlier beginning of the screening, at the age of 5 years [2] (Table 1). Some case reports of MEN1 children who developed pituitary tumors much earlier than the age of 10 are described and all three young patients had functioning macroadenomas with features of aggressiveness and treatment-resistance, thus suggesting a possible association between early development during childhood and aggressive biological behavior of pituitary tumors (cases 1, 2, and 5 , Table 3) $[6,7,10]$. Diagnostic delay seems to be quite common, ranging from almost 1.5 years to 4 years $[3,6-8$, 11] (cases 1-3, 6-8, Table 3), and it can severely compromise patients, particularly when pituitary tumors have an aggressive biological behavior.

According to current evidence [3], our series appears to show that prolactinomas were the most frequent MEN1associated pituitary tumors in childhood, similar to adulthood.

Despite the absence of young MEN1 patients with pituitary-related chronic hypercortisolism in our series and the small number of these cases reported by Goudet et al. [3], at least six cases of children with MEN1-associated Cushing's disease have been described in literature $[9,11]$ (cases 4,6-8,9,10, Table 3).

Two cases of regularly screened MEN1 girls with pituitary tumors among the other manifestations of the syndrome are reported in Table 3 (cases 12 and 13) [12].
Although MEN1 syndrome was known not to be associated with a higher incidence of pituitary carcinoma [2], and no cases occurred in our series nor in the study of Goudet et al. [3], the case of a MEN1 boy who developed a TSH-secreting pituitary carcinoma at age 19 was reported in literature [13] (case 11, Table 3).

The crucial role of patient monitoring emerges from our series, as most patients with prolactinoma were clinically asymptomatic, because the screening allowed an early laboratory and/or radiological diagnosis prior to the development of clinical manifestations, granting early therapeutic intervention. Moreover, the occurrence of a pituitary adenoma during childhood and adolescence should lead clinicians suspect MEN1 disease. Indeed, a broad study analyzing 174 not-hypercalcemic patients with a sporadic pituitary macroadenoma showed that 3 out of 46 pediatric patients ( $\leq 18$ years) suffered from MEN1, thus revealing that such adenomas were just "apparently" sporadic [14].

Considering the clinical triad of MEN1 [2], our limited series of children and adolescents showed that GEP-NETs were the rarest lesion in young MEN1 patients, in accordance with Goudet et al. [3]. To date, our patients developed only nonfunctioning pNETs, and no cases of other types of GEP-NET occurred in our study group, particularly no cases of insulinoma or gastrinoma have manifested.

Conversely, Goudet et al. [3] showed that insulinomas were the most frequent GEP-NET (12\%), followed by nonfunctioning pNET (9\%), and gastrinomas (2\%) [3]. Data of Gonçalves et al. [15] seemed to confirm our evidence on nonfunctioning pNETs, showing a higher penetrance of nonfunctioning pNETs (42\%) than insulinomas (11\%) in MEN1 patients from age 12 to 20 . The higher frequency of nonfunctioning pNET reported by Gonçalves et al. [15] with respect to Goudet et al. could be partly due to the systematic use of endoscopic ultrasound (EUS) to monitor young MEN1 patients, as EUS is more sensitive than MRI or CT and can reveal pancreatic tumors $<1 \mathrm{~cm}$ in size in asymptomatic patients.

Based on the available literature, MEN1-associated insulinoma appears to have two main features: the precocity of its onset and its significant diagnostic delay both in the pediatric population [3] and in adulthood [16]. Symptoms of neuroglycopenia could be attributed to less rare diseases, such as epilepsy, and this could partly explain the diagnostic delay. Therefore, it is very important to start screening MEN1 patients for insulinoma beginning at the age of 5 [2,3], and to educate the parents of MEN1 children to recognize clinical manifestations of insulinoma [3].

Table 3 shows two cases of children with insulinoma as the first clinical manifestation of MEN 1 [17, 18] (cases 14 and 15).

Nonfunctioning pNETs can usually be revealed through radiological investigation, because they are not hormone- 
Table 3 Clinical cases of pituitary disease and pancreatic NET in MEN1 children and adolescents

\begin{tabular}{|c|c|c|c|c|c|c|c|c|c|}
\hline $\begin{array}{l}\text { Case } \\
\text { number }\end{array}$ & Gender & $\begin{array}{l}\text { Index } \\
\text { case }\end{array}$ & $\begin{array}{l}\text { First clinical } \\
\text { manifestation(s) of } \\
\text { MEN1 }\end{array}$ & $\begin{array}{l}\text { Age at } \\
\text { diagnosis of the } \\
\text { first clinical } \\
\text { manifestation(s) } \\
\text { of MEN1 } \\
\text { (years) }\end{array}$ & $\begin{array}{l}\text { Age at first clinical } \\
\text { suspicion (years) }\end{array}$ & $\begin{array}{l}\text { Other MEN1- } \\
\text { associated lesions }\end{array}$ & Genetic information & Treatments & $\begin{array}{l}\text { Reference } \\
\text { number }\end{array}$ \\
\hline \multirow[t]{2}{*}{1} & M & Yes & $\begin{array}{l}\text { Acceleration of growth } \\
\text { and IGF1 excess-related } \\
\text { facial features in } \\
\text { presence of an invasive } \\
\text { GH/PRL-secreting } \\
\text { pituitary macroadenoma } \\
\text { inducing optic chiasm } \\
\text { compression }\end{array}$ & 5 & $\begin{array}{l}3.5=\text { acceleration of } \\
\text { growth } \\
(+13 \mathrm{~cm} / \text { year }) \text {, and } \\
\text { weight gain }\end{array}$ & Nothing & $\begin{array}{l}\text { Familial MEN1 } \\
\text { (His139Asp; exon 2) }\end{array}$ & $\begin{array}{l}\text { Bromocriptine (ineffective); L- } \\
\text { thyroxin for secondary } \\
\text { hypothyroidism. Subsequently, } \\
\text { transsphenoidaladenomectomy } \\
\text { (not curative). Pergolide, then } \\
\text { substituted by cabergoline } \\
\text { (partial control of the disease) } \\
\text { +octreotide (normalization of } \\
\text { IGF1 levels) }\end{array}$ & 6 \\
\hline & - & - & - & - & $\begin{array}{l}4=\text { worsening } \\
\text { headache }\end{array}$ & - & - & - & \\
\hline \multirow[t]{2}{*}{2} & M & Yes & $\begin{array}{l}\text { Visual disturbance } \\
\text { caused by a giant } \\
\text { prolactinoma with } \\
\text { suprasellar extension } \\
\text { inducing optic chiasm } \\
\text { compression, severe } \\
\text { hyperprolactinemia, and } \\
\text { partial hypopituitarism } \\
\text { (TSH and GH) }\end{array}$ & 11 & $7=$ chronic headache & $\begin{array}{l}\text { Subsequent primary } \\
\text { hyperparathyroidism }\end{array}$ & $\begin{array}{l}\text { Familial MEN1 } \\
\text { (consanguinity) } \\
\text { (intronic mutation } \\
784-9 \mathrm{G}>\mathrm{A} \\
\text { determining the } \\
\text { synthesis of a } \\
\text { truncated inactive } \\
\text { protein) }\end{array}$ & $\begin{array}{l}\text { L-thyroxin; cabergoline with } \\
\text { late treatment-resistance and } \\
\text { dual recurrence of pituitary } \\
\text { disease, both times treated with } \\
\text { surgical debulking ( }+\mathrm{RT} \text { after } \\
\text { the } 2^{\circ} \text { one) complicated by } \\
\text { panhypopituitarism. Planned } \\
\text { parathyroidectomy }\end{array}$ & 7 \\
\hline & - & - & - & - & $\begin{array}{l}9.5=\text { progressive } \\
\text { visual impairment }\end{array}$ & - & - & - & - \\
\hline \multirow[t]{2}{*}{3} & M & Yes & $\begin{array}{l}\text { Visual disturbance, } \\
\text { headache, mild nausea, } \\
\text { height gain }(+5 \mathrm{~cm}) \text {, } \\
\text { and feet enlargement } \\
\text { due to PRL/partially } \\
\text { GH-secreting pituitary } \\
\text { macroadenoma with } \\
\text { suprasellar extension } \\
\text { inducing obstructive } \\
\text { hydrocephalus, } \\
\text { bitemporalhemianopsia, } \\
\text { and secondary } \\
\text { hypogonadism }\end{array}$ & 19 & $\begin{array}{l}15=\text { induced } \\
\text { galactorrhea }\end{array}$ & $\begin{array}{l}\text { Simultaneous } \\
\text { diagnosis of primary } \\
\text { hyperparathyroidism } \\
\text { and a partially cystic } \\
\text { pancreatic tumor } \\
\text { associated with } \\
\text { increased levels of } \\
\text { plasma insulin }\end{array}$ & $\begin{array}{l}\text { Familial MEN1 } \\
\text { (monosomy of } \\
\text { chromosome } 11 \text { in } \\
\text { pituitary adenoma) }\end{array}$ & $\begin{array}{l}\text { Cabergoline (treatment- } \\
\text { resistance), therefore } \\
\text { transsphenoidal pituitary } \\
\text { surgery }\end{array}$ & 8 \\
\hline & - & - & - & - & $\begin{array}{l}18.5=\text { begin of overt } \\
\text { clinical } \\
\text { symptomatology }\end{array}$ & - & - & - & - \\
\hline 4 & M & $\begin{array}{l}\text { Not } \\
\text { reported }\end{array}$ & $\begin{array}{l}\text { *Cushing's syndrome } \\
\text { due to an invasive } \\
\text { pituitary microadenoma } \\
\text { positive for ACTH } \\
\text { (simultaneous presence } \\
\text { of a pituitary } \\
\text { macroadenoma positive } \\
\text { for PRL) }\end{array}$ & $* 10$ & Not reported & Angiofibromas & Familial MEN1 & $\begin{array}{l}\text { Pituitary surgery (clinically } \\
\text { curative) }\end{array}$ & 9 \\
\hline 5 & $\mathrm{~F}$ & $\begin{array}{l}\text { Not } \\
\text { reported }\end{array}$ & $\begin{array}{l}* \text { Visual disturbance and } \\
\text { acceleration of growth } \\
\text { due to an invasive GH- } \\
\text { secreting pituitary } \\
\text { macroadenoma with } \\
\text { suprasellarand lateral } \\
\text { extension inducing optic } \\
\text { chiasm compression }\end{array}$ & $* 6.5$ & Not reported & Not reported & $\begin{array}{l}\text { Familial history of } \\
\text { pituitary adenomas } \\
\text { (c. } 765-6 \mathrm{C} \rightarrow \mathrm{T} \text { - } \\
\text { splicing site; intron } \\
\text { 3) }\end{array}$ & $\begin{array}{l}\text { Transsphenoidal surgery; } \\
\text { octreotide; subsequent } \\
\text { pituitary surgery three } \\
\text { additional times, then } \\
\text { cabergoline, then RT with final } \\
\text { persistence of biochemically } \\
\text { active disease and radiological } \\
\text { evidence of the adenoma, } \\
\text { although reduced in size }\end{array}$ & 10 \\
\hline 6 & $\begin{array}{l}\text { M, } \\
\text { twin }\end{array}$ & Yes & $\begin{array}{l}\text { Cushing's disease due to } \\
\text { pituitary microadenoma }\end{array}$ & 13 & $\begin{array}{l}9=\text { deceleration of } \\
\text { growth }\end{array}$ & $\begin{array}{l}\text { Primary } \\
\text { hyperparathyroìdism } \\
\text { with urolithiasis }\end{array}$ & $\begin{array}{l}\text { Familial MEN1 } \\
\text { (Tyr351His; exon 8) }\end{array}$ & $\begin{array}{l}\text { Transsphenoidaladeno- } \\
\text { mectomy at the time of the } \\
\text { diagnosis }\end{array}$ & 11 \\
\hline 7 & $\mathrm{~F}$ & Yes & $\begin{array}{l}\text { Cushing's disease due to } \\
\text { pituitary microadenoma }\end{array}$ & 11.5 & $\begin{array}{l}7.5-8.5= \\
\text { deceleration of linear } \\
\text { growth and weight } \\
\text { gain }\end{array}$ & $\begin{array}{l}\text { Asymptomatic } \\
\text { primary } \\
\text { hyperparathy- } \\
\text { roidism; lipoma of } \\
\text { the shoulder }\end{array}$ & $\begin{array}{l}\text { Familial MEN1 } \\
\text { (Tyr351His; exon 8) }\end{array}$ & $\begin{array}{l}\text { Transsphenoidaladeno- } \\
\text { mectomy at the time of the } \\
\text { diagnosis. Surgical removal of } \\
\text { the lipoma at the age of } 16\end{array}$ & 11 \\
\hline 8 & $\mathrm{~F}$ & Yes & $\begin{array}{l}\text { Cushing's disease due to } \\
\text { pituitary microadenoma }\end{array}$ & 12.5 & $\begin{array}{l}9=\text { progressive } \\
\text { obesity and } \\
\text { deceleration of } \\
\text { growth }\end{array}$ & $\begin{array}{l}\text { Primary } \\
\text { hyperparathyroidism }\end{array}$ & $\begin{array}{l}\text { Non-familial MEN1 } \\
\text { (Leu444Pro; codon } \\
44 \text { exon 9) }\end{array}$ & $\begin{array}{l}\text { Transsphenoidaladeno- } \\
\text { mectomy at the time of the } \\
\text { diagnosis }\end{array}$ & 11 \\
\hline 9 & M & $\begin{array}{l}\text { Not } \\
\text { reported }\end{array}$ & $\begin{array}{l}\text { *Cushing's syndrome in } \\
\text { presence of } 2 \text { pituitary } \\
\text { microadenomas both } \\
\text { positive for PRL and } \\
\text { negative for ACTH plus } \\
\text { a left adrenal lesion }<1 \\
\mathrm{~cm} \text { in size }\end{array}$ & $* 15$ & Not reported & $\begin{array}{l}\text { Primary } \\
\text { hyperparathyroidism }\end{array}$ & Familial MEN1 & $\begin{array}{l}\text { Pituitary surgery (clinically } \\
\text { curative) }\end{array}$ & 9 \\
\hline 10 & M & $\begin{array}{l}\text { Not } \\
\text { reported }\end{array}$ & $\begin{array}{l}\text { *Cushing's syndrome } \\
\text { with normal hypophysis } \\
\text { also at the surgical } \\
\text { exploration; adrenal } \\
\text { imaging not determined }\end{array}$ & $* 14$ & Not reported & $\begin{array}{l}\text { Primary } \\
\text { hyperparathyroidism }\end{array}$ & Familial MEN1 & $\begin{array}{l}\text { Blind left } \\
\text { hemihypophysectomy } \\
\text { (clinically curative) }\end{array}$ & 9 \\
\hline
\end{tabular}


Table 3 continued

\begin{tabular}{|c|c|c|c|c|c|c|c|c|c|}
\hline $\begin{array}{l}\text { Case } \\
\text { number }\end{array}$ & Gender & $\begin{array}{l}\text { Index } \\
\text { case }\end{array}$ & $\begin{array}{l}\text { First clinical } \\
\text { manifestation(s) of } \\
\text { MEN1 }\end{array}$ & $\begin{array}{l}\text { Age at } \\
\text { diagnosis of the } \\
\text { first clinical } \\
\text { manifestation(s) } \\
\text { of MEN1 } \\
\text { (years) }\end{array}$ & $\begin{array}{l}\text { Age at first clinical } \\
\text { suspicion (years) }\end{array}$ & $\begin{array}{l}\text { Other MEN1- } \\
\text { associated lesions }\end{array}$ & Genetic information & Treatments & $\begin{array}{l}\text { Reference } \\
\text { number }\end{array}$ \\
\hline 11 & M & $\begin{array}{l}\text { Not } \\
\text { reported }\end{array}$ & $\begin{array}{l}\text { *Visual disturbance due } \\
\text { to TSH-secreting } \\
\text { pituitary carcinoma }\end{array}$ & $* 19$ & Not reported & $\begin{array}{l}\text { Primary hyperpara- } \\
\text { thyroidism; } \\
\text { pancreatic islet cell } \\
\text { tumors associated } \\
\text { with liver } \\
\text { adenomegaly; } \\
\text { (slowly-growing } \\
\text { periprostatic mass) }\end{array}$ & Not reported & $\begin{array}{l}\text { Transfrontalhypophysectomy } \\
+ \text { RT; pituitary hormone } \\
\text { replacement therapy. At the } \\
\text { age of } 28 \text {, occurrence of TSH- } \\
\text { secreting carcinoma metastasis } \\
\text { at foramen magnum, vertebral } \\
\text { bodies, and intradural spinal } \\
\text { level, which were surgically } \\
\text { treated (+PTU); octreotide } \\
\text { chronically. Total } \\
\text { parathyroidectomy }\end{array}$ & 13 \\
\hline 12 & $\mathrm{~F}$ & $\begin{array}{l}\text { no } \\
\text { (screened } \\
\text { patient) }\end{array}$ & $\begin{array}{l}\text { Nonfunctioning NET } \\
\text { with uncertain } \\
\text { malignant potential of } \\
\text { the neck of the } \\
\text { pancreas; } \\
\text { oligomenorrhea due to } \\
\text { hyperprolactinemia } \\
\text { associated with pituitary } \\
\text { adenoma; asymptomatic } \\
\text { primary } \\
\text { hyperparathyroidism }\end{array}$ & 14 & - & - & $\begin{array}{l}\text { Familial MEN1 } \\
\text { (frameshift) }\end{array}$ & $\begin{array}{l}\text { Partial pancreatectomy after an } \\
\text { initial period of surveillance; } \\
\text { cabergoline }\end{array}$ & 12 \\
\hline 13 & $\mathrm{~F}$ & $\begin{array}{l}\text { no } \\
\text { (screened } \\
\text { patient } \\
\text { since the } \\
\text { age of } 7 \text { ) }\end{array}$ & $\begin{array}{l}\text { Nonfunctioning NET } \\
\text { with uncertain } \\
\text { malignant potential of } \\
\text { the distal segment of the } \\
\text { pancreatic body; } \\
\text { nonfunctioning pituitary } \\
\text { microadenoma }\end{array}$ & 12 & - & - & $\begin{array}{l}\text { Familial MEN1 } \\
\text { (Gln349Stop) }\end{array}$ & $\begin{array}{l}\text { Distal pancreatectomywith } \\
\text { splenectomy }\end{array}$ & 12 \\
\hline 14 & M & Yes & $\begin{array}{l}\text { Seizures, hypoglycemic } \\
\text { symptoms, and weight } \\
\text { gain ( } 8 \mathrm{Kg} \text { during } \\
4 \text { months) due to } \\
\text { insulinoma (two } \\
\text { pancreatic lesions) }\end{array}$ & 8 & 8 & $\begin{array}{l}\text { Primary } \\
\text { hyperparathyroidism } \\
\text { at the age of } 16 ; \\
\text { hyperprolactinemia } \\
\text { with negative MRI } \\
\text { at the age of } 25\end{array}$ & $\begin{array}{l}\text { Familial MEN1 } \\
\text { (IVS4-9G > A; } \\
\text { intron 4) }\end{array}$ & $\begin{array}{l}\text { Partial pancreatectomy; } \\
\text { subtotal parathyroidectomy }\end{array}$ & 17 \\
\hline 15 & $\mathrm{~F}$ & Yes & $\begin{array}{l}\text { Sudden loss of balance, } \\
\text { tremors, and } 5 \text { min-long } \\
\text { tonic-clonic seizures } \\
\text { due to an insulinoma of } \\
\text { the head of the pancreas }\end{array}$ & 9 & $\begin{array}{l}8=\text { begin of the } \\
\text { weight gain }(+10 \mathrm{Kg} \\
\text { between } 8 \text { and } 9 \\
\text { years old })\end{array}$ & $\begin{array}{l}\text { Nothing after } 1 \text { year } \\
\text { of follow-up }\end{array}$ & $\begin{array}{l}\text { Familial MEN1 } \\
\text { (Asn374Argfs*3; } \\
\text { exon 8) }\end{array}$ & $\begin{array}{l}\text { Enucleation of the pancreatic } \\
\text { mass }\end{array}$ & 18 \\
\hline
\end{tabular}

Notes: *it is not known whether the reported clinical manifestations (and the corresponding age of their diagnosis) truly represent the first clinical manifestation of onset of MEN1 syndrome

$M$ male, $F$ female, IGF-1 insulin-like growth factor-1, $G H$ growth hormone, $P R L$ prolactin, TSH thyroid-stimulating hormone, ACTH adrenocorticotrophic hormone, NET neuroendocrine tumor, PTU propylthiouracil, $R T$ radiotherapy, MRI magnetic resonance imaging, $\mathrm{cm}$ centimeters, $\mathrm{Kg}$ kilograms

producing, or they secrete insufficient amounts of hormones, such as PP or glucagon, to induce clinical signs and symptoms [2]. Consequently, as patients are asymptomatic, imaging screening is fundamental for a timely diagnosis.

Literature highlights the high frequency of nonfunctioning pNETs in young patients with MEN1 [15], the uncertainty of their biological behavior, and the need for a careful radiological monitoring of young MEN1 patients [12]. Two clinical cases of young girls with asymptomatic nonfunctioning pNETs with uncertain malignant potential were described by Newey et al. [12] (cases 12 and 13, Table 3).

Based on results from our study, we also recommend careful and regular monitoring of young MEN1 patients for nonfunctioning pNETs through radiological imaging and test for specific pancreatic hormones, such as glucagon and PP.
Little data on MEN1-associated gastrinomas in childhood is available because they are rare in children, as opposed to in adults [3].

Given the aggressive natural history of MEN1-associated gastrinoma during childhood, and the precocious age of onset [3], despite its rarity in pediatric MEN1 patients [2,3], Goudet et al. proposed an early initiation of annual serum gastrin screening at the age of 10 [3]. However, normal levels of gastrin do not allow us to exclude the diagnosis of gastrinoma [3], and, therefore, secretin provocative tests might be helpful. Moreover, the restoration of normocalcemia after the treatment of PHPT in MEN1 patients with gastrinoma could normalize the level of fasting serum gastrin and the response to the secretin provocative test despite the presence of the gastrinoma itself, whereas the influence of the correction of PHPT-related hypercalcemia on the growth of MEN1-associated gastrinoma is not known 
[19]. The importance of educating the parents of MEN1 children in the recognition of Zollinger-Ellison syndrome through its symptomatology is crucial [3].

To date, adrenal lesions have not manifested in our patients and very few data are currently available on adrenal lesions in MEN1 children and adolescents.

Pituitary-associated Cushing's disease appears to be more frequent than Cushing's syndrome caused by adrenal lesions in pediatric MEN1 patients $[3,9,11]$.

The possibility of androgen hypersecretion in young MEN1 patients with an adrenal lesion should be kept in mind, which could reveal the presence of an adrenal carcinoma, a rare tumor that can be highly aggressive [3].

Another MEN1-associated tumor which is very rare, but extremely aggressive, is thymic NET [2,3]. No cases of such a rare tumor occurred in our series, but both young MEN1 patients with a thymic NET described in the literature died early from metastatic disease [3, 20].

MEN1 Guidelines suggest regular monitoring for this tumor even after prophylactic thymectomy [2].

In conclusion, MEN1 seems to have partially different manifestations in children and adolescents than in adults, and this may be partly justified by different diagnostic approaches between the two groups. Despite the paucity of data in literature, current evidence highlights the fundamental importance of screening for tumors in young patients with MEN1 beginning in early childhood, because clinical manifestations can occur very early, even before age 5, but we do not have sufficient experience regarding very early onset of MEN1 disease. We also strongly recommend regular monitoring of young patients at high risk of developing MEN1-associated lesions beginning in early childhood. Clinicians must be continuously attentive to the earliest signs and symptoms of MEN1-associated tumors in order to avoid diagnostic delays that could seriously jeopardize the health and survival of young patients.

Acknowledgements This study was supported by AIMEN $1 \& 2$.

\section{Compliance with ethical standards}

Conflict of interest The authors declare that they have no competing interests.

Ethical approval All procedures performed in studies involving human participants were in accordance with the ethical standards of the institutional and/or national research committee and with the 1964 Helsinki declaration and its later amendments or comparable ethical standards.

Informed consent Informed consent was obtained from all individual participants included in the study.

\section{References}

1. A. Falchetti, F. Marini, F. Tonelli, M.L. Brandi, Lessons from genes mutated in multiple endocrine neoplasia (MEN) syndromes. Ann. Endocrinol. 66, 195-205 (2005)

2. R.V. Thakker, P.J. Newey, G.V. Walls, J. Bilezikian, H. Dralle, P. R. Ebeling, S. Melmed, A. Sakurai, F. Tonelli, M.L. Brandi, Endocrine Society: Clinical practice guidelines for multiple endocrine neoplasia type 1 (MEN1). J. Clin. Endocrinol. Metab. 97, 2990-3011 (2012)

3. P. Goudet, A. Dalac, M. Le Bras, C. Cardot-Bauters, P. Niccoli, N. Lévy-Bohbot, H. du Boullay, X. Bertagna, P. Ruszniewski, F. Borson-Chazot, B. Vergès, J.L. Sadoul, F. Ménégaux, A. Tabarin, J.M. Kühn, P. d'Anella, O. Chabre, S. Christin-Maitre, G. Cadiot, C. Binquet, B. Delemer, MEN1 disease occurring before 21 years old: a 160-patient cohort study from the Groupe d'étude des tumeurs endocrines. J. Clin. Endocrinol. Metab. 100, 1568-1577 (2015)

4. C. Marcocci, M.L. Brandi, A. Scillitani, S. Corbetta, A. Faggiano, L. Gianotti, S. Migliaccio, S. Minisola, Italian Society of Endocrinology Consensus Statement: definition, evaluation and management of patients with mild primary hyperparathyroidism. J. Endocrinol. Invest. 38, 577-593 (2015)

5. N. Mitre, K. Mack, D. Babovic-Vuksanovic, G. Thompson, S. Kumar, Ischemic stroke as the presenting symptom of primary hyperparathyroidism due to multiple endocrine neoplasia type 1 . J. Pediatr. 153, 582-585 (2008)

6. C.A. Stratakis, D.H. Schussheim, S.M. Freedman, M.F. Keil, S.D. Pack, S.K. Agarwal, M.C. Skarulis, R.J. Weil, I.A. Lubensky, Z. Zhuang, E.H. Oldfield, S.J. Marx, Pituitary macroadenoma in a 5year-old: an early expression of multiple endocrine neoplasia type 1. J. Clin. Endocrinol. Metab. 85, 4776-4780 (2000)

7. Gan, H.W., Bulwer, C., Jeelani, O., Levine, M.A., Korbonits, M., Spoudeas, H.A: Treatment-resistant pediatric giant prolactinoma and multiple endocrine neoplasia type 1. Int. J. Pediatr. Endocrinol.2015, 15 (2015)

8. G. Kontogeorgos, N. Kapranos, I. Tzavara, N. Thalassinos, D. Rologis, Monosomy of chromosome 11 in pituitary adenoma in a patient with familial multiple endocrine neoplasia type 1. Clin. Endocrinol. (Oxf) 54, 117-120 (2001)

9. W.F. Simonds, S. Varghese, S.J. Marx, L.K. Nieman, Cushing's syndrome in multiple endocrine neoplasia type 1. Clin. Endocrinol. (Oxf) 76, 379-386 (2012)

10. C. Nozières, P. Berlier, C. Dupuis, C. Raynaud-Ravni, Y. Morel, F.B. Chazot, M. Nicolino, Sporadic and genetic forms of paediatric somatotropinoma: a retrospective analysis of seven cases and a review of the literature. Orphanet J. Rare Dis. 6, 67 (2011)

11. M. Rix, N.T. Hertel, F.C. Nielsen, B.B. Jacobsen, A.S. Hoejberg, K. Brixen, J. Hangaard, J.P. Kroustrup, Cushing's disease in childhood as the first manifestation of multiple endocrine neoplasia syndrome type 1. Eur. J. Endocrinol. 151, 709-715 (2004)

12. P.J. Newey, J. Jeyabalan, G.V. Walls, P.T. Christie, F.V. Gleeson, S. Gould, P.R. Johnson, R.R. Phillips, F.J. Ryan, B. Shine, M.R. Bowl, R.V. Thakker, Asymptomatic children with multiple endocrine neoplasia type 1 mutations may harbour nonfunctioning pancreatic neuroendocrine tumors. J. Clin. Endocrinol. Metab. 94, 3640-3646 (2009)

13. B.W. Scheithauer, K. Kovacs, V. Nose, M. Lombardero, Y.R. Osamura, R.V. Lloyd, E. Horvath, A. Pagenstecher, J.E. Bohl, D. S. Tews, Multiple endocrine neoplasia type 1-associated thyrotropin-producing pituitary carcinoma: report of a probable de novo example. Hum. Pathol. 40, 270-278 (2009)

14. T. Cuny, M. Pertuit, M. Sahnoun-Fathallah, A. Daly, G. Occhi, M.F. Odou, A. Tabarin, M.L. Nunes, B. Delemer, V. Rohmer, 
R. Desailloud, V. Kerlan, O. Chabre, J.L. Sadoul, M. Cogne, P. Caron, C. Cortet-Rudelli, A. Lienhardt, I. Raingeard, A.M. Guedj, T. Brue, A. Beckers, G. Weryha, A. Enjalbert, A. Barlier, Genetic analysis in young patients with sporadic pituitary macroadenomas: besides AIP don't forget MEN1 genetic analysis. Eur. J. Endocrinol. 168, 533-541 (2013)

15. T.D. Gonçalves, R.A. Toledo, T. Sekiya, S.E. Matuguma, F. Maluf Filho, M.S. Rocha, S.A. Siqueira, A. Glezer, M.D. Bronstein, M.A. Pereira, R. Jureidini, T. Bacchella, M.C. Machado, S. P. Toledo, D.M. Lourenço Jr, Penetrance of functioning and nonfunctioning pancreatic neuroendocrine tumors in multiple endocrine neoplasia type 1 in the second decade of life. J. Clin. Endocrinol. Metab. 99, E89-96 (2014)

16. A. Sakurai, M. Yamazaki, S. Suzuki, T. Fukushima, T. Imai, T. Kikumori, T. Okamoto, K. Horiuchi, S. Uchino, S. Kosugi, M. Yamada, I. Komoto, K. Hanazaki, M. Itoh, T. Kondo, M. Mihara, M. Imamura, Clinical features of insulinoma in patients with multiple endocrine neoplasia type 1: analysis of the database of the MEN Consortium of Japan. Endocr. J. 59, 859-866 (2012)

17. H.C. Fabbri, M.P. Mello, F.C. Soardi, A.M. Esquiaveto-Aun, D.M. Oliveira, F.C. Denardi, A. Moura-Neto, H.M. Garmes,
M.T. Baptista, P.S. Matos, S.H. Lemos-Marini, L.F. D'Souza-Li, G. Guerra-Júnior, Long-term follow-up of an 8-year-old boy with insulinoma as the first manifestation of a familial form of multiple endocrine neoplasia type 1. Arq. Bras. Endocrinol. Metabol. 54, 754-760 (2010)

18. E.B. Kwon, H.R. Jeong, Y.S. Shim, H.S. Lee, J.S. Hwang, Multiple endocrine neoplasia type 1 presenting as hypoglycemia due to insulinoma. J. Korean Med. Sci. 31, 1003-1006 (2016)

19. R.T. Jensen, M.J. Berna, D.B. Bingham, J.A. Norton, Inherited pancreatic endocrine tumor syndromes: advances in molecular pathogenesis, diagnosis, management, and controversies. Cancer 113, 1807-1843 (2008)

20. P. Goudet, A. Murat, C. Cardot-Bauters, P. Emy, E. Baudin, H. du Boullay Choplin, Y. Chapuis, J.L. Kraimps, J.L. Sadoul, A. Tabarin, B. Vergès, B. Carnaille, P. Niccoli-Sire, A. Costa, A. Calender, GTE network (Groupe des Tumeurs Endocrines): Thymic neuroendocrine tumors in multiple endocrine neoplasia type 1: a comparative study on 21 cases among a series of 761 MEN1 from the GTE (Groupe des tumeurs endocrines). World J. Surg. 33, 1197-1207 (2009) 